\title{
DAMPAK INDUSTRIALISASI PEDESAAN TERHADAP MODAL NAFKAH RUMAH TANGGA SEKITAR KAWASAN INDUSTRI
}

\section{Rural Industrialization Effect toward Livelihood Assets of Household Around Industrial Areas (Case In Parungmulya Village, Ciampel Sub-district, Karawang District)}

\author{
Joko H. Saputra ${ }^{1)}$ dan Murdianto ${ }^{1)}$ \\ 1) Departemen Sains Komunikasi dan Pengembangan Masyarakat, Fakultas Ekologi Manusia, Institut \\ Pertanian Bogor, Darmaga Bogor 16680, Indonesia \\ E-mail: jokosap94@gmail.com; murdiusef@gmail.com
}

\begin{abstract}
Industry in real has been succsess improving economic of Indonesia since Soeharto's regim and keep this development until now. Various of industrial expansion areas has entered into rural areas of origin is an agricultural area in Indonesia. As an agricultural country, villagers in Indonesia, many are farmers and relies heavily on the availability of land. There are five capital used by farm households to survive and improve their lives there are natural capital, human capital, physical capital, financial capital and social capital. This study aims to analyze the impact of industrialization on ivelihood of farm households. The impact can be seen by the industry non-farm employment opportunities and the buying and selling of land. While living through the fifth capital capital income. The method used is quantitative methods (questionnaire), which is supported by qualitative data.
\end{abstract}

Keywords : Business opprtunity, livelihood assets, social changes.

\begin{abstract}
ABSTRAK
Industri secara nyata telah berhasil meningkatkan perekonomian di Indonesia sejak era pemerintahan Presiden Soeharto dan terus dikembangkan hingga saat ini. Berbagai perluasan kawasan industri telah masuk ke daerah pedesaan yang asalnya merupakan daerah pertanian di Indonesia. Sebagai negara agraris, masyarakat desa di Indonesia banyak berprofesi sebagai petani dan sangat bergantung pada ketersediaan lahan. Terdapat lima modal yang digunakan oleh rumah tangga petani untuk dapat bertahan hidup dan meningkatkan kehidupan mereka yaitu modal alam, modal manusia, modal fisik, modal finansial dan modal sosial. Penelitian ini bertujuan untuk menganalisis dampak industrialisasi terhadap modal nafkah (livelihood assets) rumah tangga petani. Dampak industri dapat dilihat berdasarkan kesempatan bekerja non pertanian dan jual-beli lahan. Sementara itu modal nafkah melalui kelima modal nafkah. Metode yang digunakan adalah metode kuantitatif (kuesioner) yang didukung dengan data kualitatif.
\end{abstract}

Kata Kunci : Kesempatan usaha, livelihood assets, perubahan sosial

\section{PENDAHULUAN}

Hadirnya modernisasi di dunia membuat sebagian besar negara berkiblat ke negara barat dalam hampir seluruh aspek kehidupan, dan menempatkan ekonomi sebagai aspek utama dalam pembangunan (Sztompka 1993). Tidak heran jika akhirnya muncul kelompok-kelompok negara berdasarkan tingkatan ekonomi tertentu agar negara yang masih berada di kelas bawah (miskin atau berkembang) berusaha mengubah nasibnya untuk meningkatkan perekonomian sehingga keberadaannya mencapai tingkat yang lebih tinggi (maju). Setidaknya hal itu yang dilakukan oleh Pemerintah Indonesia pada zaman orde baru. Sejak permulaan PELITA II, 
pertumbuhan ekonomi menjadi sasaran pembangunan utama pemerintah atas krisis yang terjadi. Salah satu cara yang digunakan untuk meningkatkan laju pertumbuhan ekonomi adalah melalui industrialisasi (Mirajiani 2003).

Sanderson seperti dikutip oleh Mirajiani (2003) mengartikan industrialisasi sebagai proses yang membuat masyarakat mengikuti suatu sistem ekonomi dan bentuk kehidupan-kehidupan sosial yang didasarkan atas kerja mesin-mesin dan sistem pabrik. Fenomena ini erat kaitannya dengan sistem sosial masyarakat yang umumnya berada di perkotaan. Akan tetapi, fenomena industrialisasi saat ini semakin menjamur dan semakin banyak mengarah ke pedesaan yang mayoritas masyarakatnya menganut sistem agraris-tradisional.

Industri yang berkembang di pedesaan umumnya bukan dimiliki oleh masyarakat asli desa, melainkan orang luar desa yang memanfaatkan sumber daya sekitar guna kepentingan dirinya dan para investor (Sulasmono 1994). Semakin masifnya industri di Indonesia diharapkan menambah jumlah investor untuk masuk dan menanamkan modalnya di Indonesia sehingga pertumbuhan agregat ekonomi Indonesia terus mengalami peningkatan. Hal ini sesuai dengan amanat Undang-undang Nomor 3 tahun 2014 tentang Perindustrian Pasal 14 ayat 1 yang berbunyi "Pemerintah dan/atau Pemerintah Daerah melakukan percepatan penyebaran dan pemerataan pembangunan Industri ke seluruh wilayah Negara Kesatuan Republik Indonesia melalui perwilayahan Industri”. Dipilihnya desa sebagai lokasi industri menurut Sulasmono (1994) karena wilayah pedesaan memiliki keuntungan tersendiri bagi pengembangan industri dibanding kota. Keuntungan tersebut diantaranya yaitu melimpahnya ketersediaan sumber daya alam, tenaga kerja murah, terhindar dari protes, dan bahkan keterbelakangan masyarakat. Padahal sejatinya desa di Indonesia selama ini merupakan basis penyedia pangan pokok karena lahan pertanian selama ini terdapat di pedesaan. Akan tetapi, kemiskinan hingga saat ini justru masih lebih banyak terdapat di pedesaan daripada perkotaan.
Nafkah merupakan hal yang penting bagi rumah tangga untuk tetap mempertahankan hidup atau meningkatkan kualitas hidupnya. Nafkah yang dijalankan oleh suatu rumah tangga setidaknya terdapat lima modal yang menentukan. Kelima modal nafkah ini menurut Ellis (2000) yaitu modal alam, modal manusia, modal fisik, modal finansial dan modal sosial. Modal alam merujuk pada sumber daya alam dasar (tanah, air, pohon) yang menghasilkan produk yang digunakan oleh populasi manusia untuk kelangsungan hidup mereka. Modal fisik merujuk pada aset-aset yang dibawa ke dalam eksistensi proses produksi ekonomi, sebagai contoh, alat-alat, mesin, dan perbaikan tanah seperti teras atau saluran irigasi. Modal manusia merujuk pada tingkat pendidikan dan status kesehatan individu dan populasi. Modal finansial merujuk pada persediaan uang tunai yang dapat diakses untuk membeli barangbarang konsumsi atau produksi, dan akses pada kredit dapat dimasukkan ke dalam kategori ini. Modal sosial merujuk pada jaringan sosial dan asosiasi di mana orang berpartisipasi, dan dari mana mereka dapat memperoleh dukungan yang memberikan kontribusi terhadap penghidupan mereka. Kelima modal ini yang nantinya menentukan cara rumah tangga petani menerapkan sistem atau strategi nafkah mereka untuk mempertahankan kehidupan.

Masih tingginya tingkat kesmiskinan di pedesaan dapat disebabkan salah satunya masih terbatasnya masyarakat dalam mengakses modal nafkah. Modal nafkah yang yang terbatas, membuat masyarakat sulit mengembangkan aktivitas nafkah sehingga kualitas dari kelangsungan hidup menjadi rendah. Industrialisasi yang membawa perubahan bagi suatu wilayah sangat berpotensi mengubah modal nafkah yang biasa dimanfaatkan oleh masyarakat sekitar. Jika tidak dikendalikan dan diantisipasi, dikhawatirkan modal nafkah justru akan menimbulkan kerugian bagi aktivitas nafkah masyarakat.

Salah satu desa yang menjadi wilayah industri di Kabupaten Karawang adalah Desa Parungmulya yang berada di Kecamatan Ciampel. Desa Parungmulya merupakan kawasan yang sebagian besar wilayahnya merupakan Kawasan Industri Mitra Karawang (KIM). Perubahan yang terjadi 
di Desa Parungmulya dapat dirasakan dalam hal geografi, sosial dan ekonomi. Untuk itu, menjadi penting untuk diteliti mengenai bagaimana pendirian industri mempengaruhi kesempatan usaha dan jual-beli lahan?

Modal nafkah sebagai sumber penghidupan menentukan keberlangsungan hidup suatu rumah tangga. Modal nafkah menurut Ellis (2000) diartikan sebagai unsur-unsur penting yang mendukung aktivitas nafkah rumah tangga setiap harinya. Unsur-unsur ini terdiri atas modal alam, modal manusia, modal fisik, modal sosial dan modal finansial. Sehingga menjadi menarik untuk diteliti tentang bagaimana perubahan modal nafkah yang terjadi setelah dan sebelum adanya industri?

Hadirnya industrialisasi yang menimbulkan perubahan bagi keadaan sekitar kawasan industri memberi dampak pada modal nafkah yang sebelumnya dimiliki oleh rumah tangga. Hadirnya industrialisasi ini diharapkan memberi dampak yang positif bagi modal nafkah rumah tangga di Desa Parungmulya. Akan tetapi, dikhawatirkan jika hadirnya industrialisasi justru tidak memberikan perubahan atau bahkan memberi perubahan yang negatif bagi modal nafkah rumah tangga. Sehingga menarik untuk diteliti tentang bagaimana hubungan kesempatan usaha dan jual beli lahan sebagai dampak industrialisasi pedesaan terhadap modal alam, modal manusia, modal fisik, modal finansial dan modal sosial rumah tangga?

\section{PENDEKATAN TEORITIS}

\section{Industrialisasi}

Sanderson seperti dikutip oleh Mirajiani (2003) mengartikan industrialisasi sebagai proses yang membuat masyarakat mengikuti suatu sistem ekonomi dan bentuk kehidupan-kehidupan sosial yang didasarkan atas kerja mesin-mesin dan sistem pabrik. Melalui industrialisasi ini perubahan-perubahan yang luas dalam kehidupan masyarakat diharapkan dapat terjadi (Purwanto 2003). Industrialisasi merupakan sebuah fenomena yang di dalamnya terdapat proses interaksi antara faktor-faktor industri seperti faktor produksi, teknologi, pengusaha dan sistem kerja dengan sistem sosial masyarakat sekitar (Mirajiani 2003). Hal inilah yang menurut Gandi (2011), industrialisasi dapat memicu suatu perubahan sosial di masyarakat. Melalui industrialisasi, fungsi teknologi menjadi semakin penting untuk diterapkan dalam proses produksi. Akibatnya hubungan antar manusia menjadi berubah, demikian juga struktur sosial masyarakat di sekitarnya.

Adapun berkembangnya industri di pedesaan, White (1990) membagi industri di pedesaan menjadi lima jenis, yaitu:

1. Industri yang mengandalkan pasaran lokal (local market based industries)

2. Industri yang berdasarkan sumber daya bahan baku lokal (local resource-based industries)

3. Industri yang mengandalkan tenaga kerja murah (low wage based industries)

4. Industri-industri "kotor"

5. Industri yang berlokasi di pedesaan bukan karena faktor keunggulan lokasi atau karena tujuan tertentu, melainkan karena diwajibkan oleh pihak berwenang sesuai dengan rencana tata ruang setempat.

\section{Dampak Industrialisasi}

Data pada BPS (2015) menunjukkan bahwa laju pertumbuhan produk domestik bruto (PDB) dari sektor industri pengolahan lebih menunjukkan konsisten meningkat daripada sektor pertanian, kehutanan dan perikanan. Seperti yang dikatakan oleh Gandi (2011), bahwa hadirnya industri dapat mengatasi masalah kesempatan kerja akibat semakin menyempitnya pekerjaan di sektor pertanian di pedesaan. Beberapa alasan rasional yang diungkapkan Rahardjo seperti dikutip oleh Gandi (2011) mengenai alasan mengapa sektor industri lebih penting untuk dikembangkan daripada sektor pertanian, yaitu pertama karena penanaman modal di sektor pertanian dinilai kurang menguntungkan. Hal ini terjadi karena tekanan perkembangan penduduk yang terus menerus, maka bidang ini akan makin terkena hukum "hasil yang makin kecil" (law of deminishing return). Alasan lain adalah, bahwa sektor pertanian dianggap lambat pertumbuhannya, bahkan berkecenderungan 
stagnan, antara lain disebabkan karena terdapatnya hambatan sosial dan institusional yang sulit diubah, setidak-tidaknya dalam tempo cepat. Transformasi sektor pertanian dalam konteks modernisasi, hal ini industrialisasi, di kawasan pedesaan yang menimbulkan masalahmasalah kesempatan kerja. Dampak lain yang muncul dari adanya industrialisasi yaitu:

1. Meningkatnya migrasi masuk. Dibukanya suatu perusahaan akan membuat terbukanya lapangan pekerjaan. Hal ini yang membuat masyarakat dari berbagai daerah berkumpul menuju lokasi perusahaan untuk bekerja di sana. Besarnya kebutuahn tenaga kerja oleh perusahaan diiringi dengan kriteria-kriteria tertentu, seperti jenis kelamin, tingkat pendidikan, ataupun status perkawinan (Sulasmono 1994).

2. Meningkatnya konversi lahan. Konversi lahan yang terjadi sekitar kawasan industri terjadi akibat perluasan industri oleh perusahaan, bahkan tidak jarang hal ini turut membuat lahan pertanian di suatu desa juga menjadi sasaran perluasan kawasan (Sutrisna 2008).

3. Kesempatan bekerja diluar sektor pertanian. Adanya industri di suatu daerah membuka kesempatan kerja di industri tersebut, terutama jika di pedesaan mengundang minat masyarakat sekitar untuk bekerja di perusahaan. Pekerjaan yang disediakan seperti menjadi buruh, petugas keamanan, ataupun petugas kebersihan. Selain itu, beberapa pekerjaan yang muncul setelah hadirnya industri seperti usaha transportasi (ojek), penyewaan tempat tinggal dan usaha warung.

4. Jual-beli lahan. Jual lahan dan beli lahan merupakan hal penting yang terjadi akibat hadirnya indutri di suatu wilayah. Peruntukan lahan yang semulanya lahan kering atau pertanian mayoritas untuk perumahan yang menampung para pendatang yang bekerja di industri tersebut (Gandi 2011)

\section{Nafkah}

Poin utama dalam memahami nafkah adalah kepemilikan, kontrol, penguasaan terhadap suatu aset atau beberapa pengertian lain yang dapat diakses oleh rumah tangga. Aset sendiri merupakan ketersediaan atas modal yang dapat dimanfaatkan secara langsung atau tidak langsung untuk menghasilkan cara bertahan hidup atau untuk meningkatkan taraf hidup suatu rumah tangga (Ellis 2000). Scoones (1998) mengartikan aset livelihood dalam istilah livelihood resources yang terdiri atas modal alam, modal ekonomi atau modal finansial, modal manusia dan modal sosial.

Terdapat lima modal yang dijelaskan Ellis sebagai livelihood asset yaitu modal alam, modal fisik, modal manusia, modal finansial, dan modal sosial. Kelima livelihood assets ini erat kaitannya dengan sumber nafkah masyarakat agraris, yaitu:

1. Modal Alam (Natural Capital). Modal alam terdiri atas tanah, air dan sumber daya biotik yang digunakan seseorang untuk dapat bertahan hidup. Modal ini bisa juga disebut sebagai lingkungan di sekitar manusia yang merupakan gabungan dari berbagai faktor biotik dan abiotik.

2. Modal Fisik (Physical Capital). Modal fisik merupakan modal yang berbentuk infrastruktur dasar atau merujuk pada asetaset dalam proses produksi ekonomi, seperti alat-alat, mesin, saluran irigasi, jalan, gedung, dan lain sebagainya.

3. Modal Finansial (Financial Capital). Modal ini berupa uang, yang digunakan oleh suatu rumahtangga. Modal ini dapat berupa uang tunai, tabungan, ataupun akses dan pinjaman.

4. Modal Manusia (Human Capital). Modal ini merupakan modal yang ada dalam diri manusia. Modal ini berupa tenaga kerja yang tersedia dalam rumahtangga yang dipengaruhi oleh pendidikan, keterampilan, dan kesehatan untuk dapat memenuhi kebutuhan hidupnya.

5. Modal Sosial (Social Capital). Modal ini merupakan gabungan komunitas yang dapat memberikan keuntungan bagi individu atau rumahtangga yang tergabung di dalamnya.

\section{Kerangka Pemikiran}

Hadirnya industri di sebuah desa mengakibatkan suatu perubahan bagi masyarakat sekitar, baik dalam hal geografis maupun struktur sosialekonomi. Fenomena industrialisasi setidaknya mengakibatkan berbagai fenomena yang dalam penelitian ini disebut sebagai dampak 
industrialisasi, yaitu peluang usaha rumah tangga dan jual-beli lahan. Terjadinya peluang usaha rumah tangga dilatarbelakangi oleh kenyataan bahwa desa identik dengan pertanian yang mayoritas masyarakatnya bekerja sebagai petani. Dengan hadirnya industri, peluang pekerjaan menjadi meningkat salah satunya membuka usaha secara mandiri akibat perubahan demografis yang terjadi. Peluang usaha ini didasarkan menurut Sulasmono (1994) yaitu usaha warung-warungan, usaha jasa, limbah dan ditambah dengan usaha pemondokan. Sementara itu jual beli-lahan merupakan fenomena yang terjadi akibat kebutuhan akan wilayah industri itu sendiri. Selain itu, peruntukan lahan juga dapat dipergunakan sebagai lokasi usaha masyarakat, pembangunan jalan dan perumahan.

Nafkah rumah tangga petani yang terdiri atas lima modal nafkah yaitu modal alam, modal manusia, modal sosial, modal fisik dan modal finansial mereka gunakan untuk bertahan hidup dan meningkatkan kualitas hidup mereka. Kelima modal nafkah ini senantiasa beradaptasi atas suatu fenomena perubahan yang terjadi di suatu wilayah. Suatu rumah tangga yang memanfaatkan peluang usaha memiliki kemungkinan untuk memperkaya nafkah mereka melalui penguasaan atas modal-modal nafkah yang dapat diidentifikasi, seperti penggunaan karyawan sebagai usaha sebagai bentuk dari pemanfaatan modal manusia, pemilikan aset fisik tertentu sebagai bentuk penguasaan modal fisik, tambahan penghasilan untuk ditabung sebagai bentuk modal finansial atau bahkan tergabungnya dalam serikat organisasi tertentu sebagai bentuk modal sosial. Selain itu, jual-beli lahan yang dilakukan rumah tangga petani juga memungkinkan hal yang sama. Rumah tangga yang mulanya memiliki lahan yang luas dan menjualnya bagi pihak lain terutama untuk perusahaan memiliki kemungkinan bertambahnya modal finansial yang mereka miliki dan fasilitas fisik lain sebagai penyangga nafkah rumah tangga. Selain itu, jika penguasaan modal nafkah rumah tangga semakin banyak maka pendapatan rumah tangga menjadi lebih banyak pula yang dilingkup oleh usaha-usaha yang mereka lakukan dalam bidang on-farm, offfarm maupun non-farm.
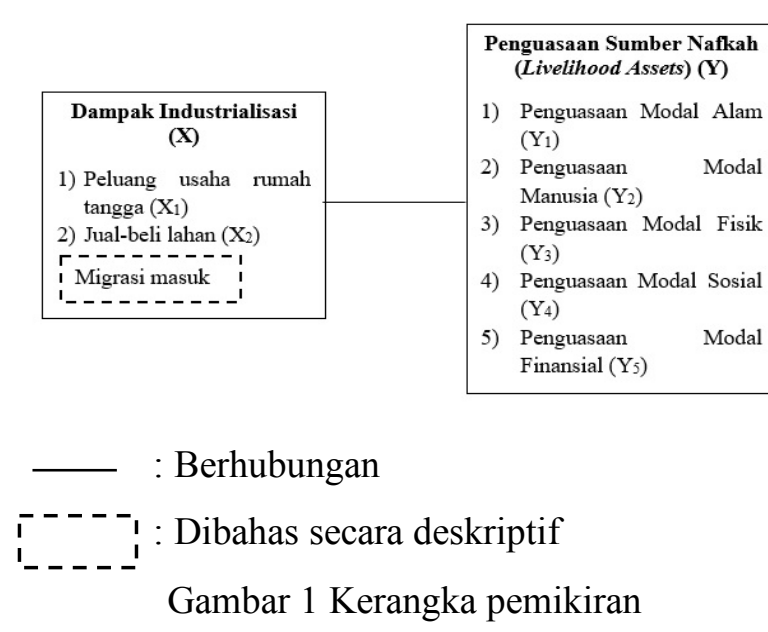

\section{Hipotesis}

1. Terdapat hubungan antara peluang usaha rumah tangga dengan penguasaan modal alam.

2. Terdapat hubungan antara peluang usaha rumah tangga dengan penguasaan modal manusia.

3. Terdapat hubungan antara peluang usaha rumah tangga dengan penguasaan modal ekonomi.

4. Terdapat hubungan antara peluang usaha rumah tangga dengan penguasaan modal sosial.

5. Terdapat hubungan antara peluang usaha rumah tangga dengan penguasaan modal fisik.

6. Terdapat hubungan antara jual-beli lahan dengan penguasaan modal alam.

7. Terdapat hubungan antara jual-beli lahan dengan penguasaan modal manusia.

8. Terdapat hubungan antara juat-beli lahan dengan penguasaan modal ekonomi.

9. Terdapat hubungan antara jual-beli lahan dengan penguasaan modal sosial.

10. Terdapat hubungan antara jual-beli lahan dengan penguasaan modal fisik.

\section{PENDEKATAN LAPANG}

Penelitian ini dilaksanakan di dua dusun yaitu Dusun Simargalih dan Dusun Griya Indah, Desa Parungmulya, Kecamatan Ciampel, Kabupaten Karawang, Jawa Barat. Dipilihnya Desa Parungmulya karena di desa ini terdapat kawasan industri yaitu Kawasan Industri Mitra Karawang 
(KIM) yang luasnya mencapai 100 hektar. Berdasarkan hasil observasi, Desa Parungmulya sangat terlihat perubahan masyarakat yang mulanya agraris menjadi masyarakat urban. Hal ini karena masih adanya persawahan dan sungai irigasi di desa ini. Selain itu, fakta ini juga diperkuat dengan pendapat Kepala Desa Parungmulya bahwa dahulu mayoritas masyarakat di desa ini memiliki mata pencaharian sebagai petani atau buruh tani dan saat ini berubah menjadi buruh/karyawan dan pedagang. Penelitian ini dilaksanakan selama enam bulan yaitu pada Bulan Februari 2017 hingga Bulan Juli 2017. Kegiatan penelitian meliputi studi literatur, penyusunan proposal skripsi, kolokium, pengambilan data di lapangan, pengolahan data, analisis data, penyusunan draft skripsi, uji petik, sidang skripsi dan revisi laporan penelitian.

Penelitian yang dilakukan merupakan jenis penelitian eksplanatori yang bertujuan untuk menjelaskan hubungan antar-variabel melalui pengujian hipotesis penelitian. Pendekatan yang digunakan dalam penelitian adalah pendekatan kuantitatif yang didukung dengan data-data kualitatif. Pendekatan kuantitatif dilakukan dengan metode survei melalui instrumen berupa kuesioner yang diberikan kepada responden. Perubahan diukur dengan melihat kondisi faktual sebelum hadirnya industri dengan setelah adanya industri yang dialami oleh responden. Sementara data kualitatif diperoleh melalui wawancara mendalam kepada informan dan melalui catatan harian lapang. Data kualitatif ini digunakan untuk mendukung dan meginterpretasikan data yang didapat melalui pendekatan kuantitatif mengenai dampak industrialisasi, modal nafkah rumah tangga dan hubungan antara dampak industrialisasi dengan modal nafkah rumah tangga.

Sebelum mengumpulkan data penelitian melalui kuesioner, terlebih dahulu dilakukan tes validitas dan reliabilitas terhadap instrumen penelitian yang digunakan. Uji validitas dan reliabilitas dilakukan dengan menguji kuesioner sebagai indtrumen penelitian kepada 10 responden dengan karakteristik sama dengan sampel penelitian. Nilai alpha yang didapat dalam uji realibilitas adalah 0,711 yang memiliki arti reliabilitas tinggi.

Populasi dalam penelitian ini adalah rumah tangga yang berada di dua dusun yaitu Dusun Simargalih dan Dusun Griya Indah di Desa Parungmulya yang saat ini membuka usaha akibat keberadaan industri di wilayah tersebut. Penentuan sampel dilakukan menggunakan teknik random sampling yang dipilih dari kerangka sampling yang telah disusun sebelumnya. Kerangka sampling merupakan daftar populasi yang digunakan dalam penelitian ini yang didapat melalui keterangan dari masingmasing ketua rukun tangga (RT) di dua dusun. Dari nama-nama yang terpilih, peneliti kemudian mendatangi dan mewawancarai responden satupersatu sampai terpilih sebanyak 30 responden untuk masing-masing dusun. Sementara itu, pemilihan informan dilakukan secara purposive (sengaja) yaitu berdasarkan informasi antara responden di lokasi penelitian.

Data yang digunakan dalam penelitian ini terdiri atas data primer dan sekunder. Data primer merupakan data yang didapat langsung di lokasi penelitian dengan cara observasi, kuesioner, serta wawancara mendalam yang dilakukan langsung kepada responden maupun informan. Data sekunder diperoleh dari dokumen-dokumen tertulis antara lain profil desa dan hasil penelitian akademisi sebelumnya. Pengolahan data dilakukan melalui reduksi data, baik data kuantitatif maupun kualitiatif dengan tujuan memusatkan, memilih, dan menyederhanakan data sehingga dapat digunakan untuk menjawab tujuan penelitian. Data yang didapat melalui kuesioner, catatan harian, catatan lapang, dan hasil wawancara mendalam terlebih dahulu dicek kelengkapan dan kekonsistenannya sebelum diolah. Selanjutnya data hasil kuesioner dimasukkan ke dalam aplikasi MS Excel 2013 dan diuraikan sesuai variabel. Pengolahan selanjutnya adalah menggunakan SPSS Statistic 16.0 untuk mengukur hubungan dua variabel menggunakan tabulasi silang serta menggunakan uji korelasi rank spearman untuk melihat kekuatan hubungan antara dampak industrialisasi dengan sumber nafkah yang dikuasai oleh rumah tangga petani. Dipilahnya uji statistik korelasi rank-sperman 
karena data yang digunakan merupakan data ordinal. Taraf nyata yang digunakan dalam pengolahan data kuantitatif adalah 95 persen atau nilai $\alpha$ sebesar 5 persen $(0,05)$.

\section{HASIL DAN PEMBAHASAN}

\section{Dampak Industrialisasi Pedesaan}

\section{Kesempatan Usaha}

Kelompok responden Dusun Simargalih sebelum hadirnya industri sebanyak 80,0 persen tidak memiliki usaha. Sementara yang lainnya yaitu sebanyak 10,0 persen telah membuka usaha warung, 6,7 persen membuka usaha pengelolaan limbah dan sisanya sebesar 3,3 persen membuka usaha kuliner. Dari 80,0 persen responden yang belum membuka usaha saat sebelum hadirnya industri, mayoritasnya memiliki pekerjaan sebagai petani. Hal ini karena sebelum hadirnya industri, kawasan di Desa Simargalih adalah kawasan pertanian dan hampir seluruhnya merupakan petani dan buruh tani. Ketika industri datang, kawasan pertanian yang ada berubah menjadi kawasan industri, sehingga memaksa para penduduk mengubah mata pencaharian mereka yaitu dengan membuka usaha. Persentase masyarakat yang membuka usaha lebih dari satu jenis usaha adalah yang tertinggi yaitu sebesar 43,3 persen. Responden yang membuka usaha lebih dari satu jenis usaha umumnya adalah usaha pemondokan beserta warung atau rumah makan, karena dua jenis usaha ini akan saling menguntungkan dan memberikan pendapatan yang lebih besar.

Pada kelompok responden Dusun Griya Indah sebanyak 80,0 responden sebelum adanya industri memiliki usaha setelah hadirnya industri. Sebanyak 10,0 persen responden memiliki usaha warung sebelum adanya industri dan 10,0 persen lainnya memiliki usaha kuliner sebelum hadirnya industri. Setelah hadirnya industri, persentase terbesar responden yaitu memiliki lebih dari satu jenis usaha yaitu sebesar 33,3 persen.

\section{Jual-beli Lahan}

Aktivitas jual-beli lahan terlihat tinggi jumlahnya pada kelompok responden Dusun Simargalih. Hal ini beralasan bahwa masyarakat yang tinggal di Dusun Simargalih mayoritas adalah masyarakat asli yang mengalami pembebasan lahan saat dibangunnya kawasan industri. Sebanyak 98,3 persen dari lahan yang dijual setelah industri pada kelompok responden Dusun Simargalih diperuntukan bagi pembangunan kawasan industri. Selain menjual lahan, setelah hadirnya industri responden juga melakukan pembelian lahan. Peruntukan tertinggi dari aktivitas membeli lahan ini adalah untuk usaha nonpertanian yaitu sebesar 92,6 persen. Pada kelompok responden Dusun Griya Indah, meskipun terdapat peningkatan aktivitas jual-beli lahan setelah hadirnya industri, namun jumlahnya lebih sedikit jika dibandingkan dengan kelompok responden di Dusun Simargalih. Hal ini karena mayoritas penduduk di dusun ini merupakan pendatang sehingga tidak merasakan pembebasan lahan ketika kawasan industri dibangun.

\section{Migrasi Masuk}

Migrasi masuk yang terjadi di Desa Parungmulya dapat dikatakan tinggi. Hal ini dapat dilihat dari data profil desa pada tiga tahun terakhir yang selalu mengalami peningkatan. Selain itu, berdasarkan keterangan dari responden dan informan juga menunjukkan bahwa jumlah penduduk saat ini jauh lebih tinggi jika dibandingkan sebelum adanya industri, bahkan terus meningkat tidap tahunnya. Berdasarkan dari keterangan responden yang sudah diwawancarai, sebagian besarnya merupakan migran. Hadirnya Dusun Griya Indah, menurut tokoh setempat adalah dusun yang 80 persennya diisi oleh migran yang berasal dari luar Kabupaten Karawang. Masyarakat yang melakukan migrasi memiliki alasan yang berbeda-beda, namun alasan paling banyak adalah dalam hal nafkah atau mencari pekerjaan. Masyarakat yang melakukan migrasi adalah dalam rangka memanfaatkan hadirnya industri seperti terbukanya lapangan pekerjaan baru, tingginya jumlah penduduk dan adanya keahlian yang dapat dimanfaatkan dalam memanfaatkan industrialisasi yang terjadi. Faktor yang menjadi alasan penduduk untuk bermigrasi ke Desa Parungmulya adalah adanya rekrutmen 
tenaga kerja oleh perusahaan, adanya peluang yang tinggi untuk membuka usaha dan adanya relasi di daerah tujuan.

\section{Modal Nafkah}

\section{Penguasaan Modal Alam}

Pada Dusun Simargalih, terjadi penurunan akses pada jumlah sumber daya alam yang dikuasai hingga hampir 50,0 persen. Jenis SDA yang diukur dalam penelitian ini adalah sawah, kebun, hutan, sungai dan danau. Jumlah akses pada SDA jenis sawah mengalami penurunan jumlah yang tertinggi sekitar 85,7 persen dari jumlah sebelum adanya industri. Sementara itu jumlah penguasaan terhadap sungai meningkat 40,0 persen dari jumlah awal. , jumlah SDA yang dapat diakses oleh responden di Dusun Griya Indah terlihat lebih sedikit jika dibandingkan dengan kelompok responden Dusun Simargalih. Hal ini dapat dilihat dari total SDA yang dapat diakses yang mencapai setengahnya pada keadaan sebelum industri. Sementara itu pada keadaan setelah dan sebelum industri sama-sama terjadi penurunan, namun pada kelompok responden di Dusun Griya Indah tidak terjadi penurunan yang signifikan.

Tabel 1 Perubahan jumlah dan persentase responden Desa Parungmulya menurut penguasaan modal alam tahun 2017

\begin{tabular}{llrr}
\hline \multirow{2}{*}{ Dusun } & Penguasaan & \multicolumn{2}{c}{ Perubahan } \\
& Modal Alam & (Setelah-sebelum) \\
\cline { 3 - 4 } & & Jumlah & $\%$ \\
\hline \multirow{4}{*}{ Dusun } & Rendah & 12 & 40,0 \\
Simargalih & Sedang & -7 & $-23,3$ \\
& Tinggi & -5 & $-16,7$ \\
\cline { 2 - 4 } & Total & 0 & 0,0 \\
\hline \multirow{3}{*}{ Dusun } & Rendah & 2 & 6,7 \\
Griya & Sedang & -2 & $-6,7$ \\
Indah & Tinggi & 0 & 0,0 \\
\cline { 2 - 4 } & Total & 0 & 0,0 \\
\hline
\end{tabular}

Terjadi perubahan penguasaan modal alam ke kategori rendah. Pada kelompok responden Dusun Simargalih, perubahan ke kategori rendah meningkat hingga 40,0 persen, bahkan responden pada kategori tinggi sudah tidak ada lagi setelah hadirnya industri. Sementara pada kelompok responden di Dusun Griya Indah, responden kategori rendah masih yang tertinggi baik saat sebelum industri maupun setelah hadirnya industri. Perubahan yang terjadi ada pada kategori sedang, yang turun menjadi kategori rendah sebanyak 6,7 persen. Hal ini diterangkan lebih lanjut pada Tabel 1.

\section{Penguasaan Modal Manusia}

Pada kelompok responden Dusun Simargalih, rata-rata jumlah keahlian responden meningkat setelah hadirnya industri, dengan persentase sebesar 35,7 persen dari jumlah awal. Peningkatan tertinggi terjadi pada keahlian dalam berdagang. Sementara keahlian lain yang dimiliki oleh responden yang meningkat seperti pengelolaan limbah dan kuliner. Adanya penurunan keahlian terdapat pada jenis bertani hal ini karena umur responden yang semakin tua membuatnya suit untuk melakukan aktivitas fisik di lahan, selain itu beberapa responden juga mengaku tidak bisa bertani saat ini karena sudah terlalu lama tidak bertani sehingga akan kesulitan jika harus bertani kembali.

Tabel 2 Perubahan jumlah dan persentase responden Desa Parungmulya menurut penguasaan modal manusia tahun 2017

\begin{tabular}{llrr}
\hline \multirow{2}{*}{ Dusun } & Penguasaan & \multicolumn{2}{c}{$\begin{array}{c}\text { Perubahan (Setelah- } \\
\text { sebelum) }\end{array}$} \\
\cline { 3 - 4 } & Modal & Jumlah & $\%$ \\
\hline \multirow{3}{*}{ Dusun } & Rendah & -9 & $-30,0$ \\
Simargalih & Sedang & 0 & 0,0 \\
& Tinggi & 9 & 30,0 \\
\cline { 2 - 4 } & Total & 0 & 0,0 \\
\hline \multirow{3}{*}{ Dusun } & Rendah & -6 & $-20,0$ \\
Griya & Sedang & -7 & $-23,3$ \\
& Tinggi & 13 & 43,3 \\
\cline { 2 - 4 } & Total & 0 & 0,0 \\
\hline Pada & Duriya & &
\end{tabular}

Pada Dusun Griya Indah, responden juga mengalami peningkatan jumlah keahlian yang cukup tinggi yaitu sebesar 42,8 persen dari jumlah awal atau sebelum adanya industri. 
Adanya peningkatan keahlian pada kelompok responden ini lebih disebabkan oleh pendidikan yang mereka tempuh dan kehidupan awal responden sebelum tinggal di Desa Parungmulya. Mayoritas responden di Dusun Griya Indah ini menempuh pendidikan hingga ke jenjang SMA, bahkan beberapa di antaranya mencapai perguruan tinggi. pendidikan yang relatif tinggi ini membuat responden dapat diterima sebagai karyawan di perusahaan, sehingga keahlian mereka menjadi bertambah.

Berdasarkan Tabel 2, perubahan meningkat yang lebih besar pada kelompok responden di Dusun Griya Indah disebabkan oleh beberapa hal, seperti jenjang pendidikan terakhir yang lebih tinggi, relatif mempekerjakan karyawan dan kesehatan yang masih baik karena umur responden yang masih berada di usia produktif. Dalam hal jenjang pendidikan formal terakhir, rata-rata responden di Dusun Griya Indah berhasil tamat hingga SMA dan perguruan tinggi. Ini yang menjadi alasan utama masyarakat di Dusun Griya Indah hampir seluruhnya merupakan karyawan/ buruh di perusahaan di kawasan indsutri. Berbeda dengan kelompok responden Dusun Simargalih yang rata-rata menamatkan pendidikan pada jenjang sekolah dasar dan sekolah menengah pertama.

\section{Penguasaan Modal Fisik}

Pada pengukuran modal fisik ini hal yang dinilai adalah kepemilikan rumah tangga atas beberapa perlengkapan atau alat rumah tangga, seperti kendaraan pribadi, perlengkapan rumah tangga dan perlengkapan tertentu yang mendukung usaha rumah tangga. Penguasaan modal fisik ini dikategorikan dalam tiga kelas, yaitu rendah, sedang dan tinggi. Pengkategorian ini kemudian dilihat pula perubahannya saat sebelum hingga setelah hadirnya industri.

Pada Tabel 3 terlihat bahwa pada kelompok responden di Dusun Simargalih terjadi perubahan meningkat pada kategori sedang sebesar 46,7 persen dan pada kategori tinggi juga meningkat sebesar 26,7 persen. Sementara pada kategori rendah, turun sebesar 73,3 persen. Artinya, bahwa pada kelompok responden di Dusun Simargalih setelah hadirnya industri seluruhnya mengalami peningkatan pada penguasaan modal fisik. Pada kelompok responden di Dusun Griya Indah juga terjadi perubahan meningkat pada kategori tinggi setelah adanya industri, yaitu sebesar 86,7 persen. Sedangkan pada kategori rendah terjadi penurunan sebesar 76,7 persen dan pada kategori rendah juga mengalami penurunan sebesar 10,0 persen. Bahkan, jumlah responden pada kategori rendah setelah hadirnya industri sudah 0,0 persen.

Tabel 3 Perubahan jumlah dan persentase responden di Desa Parungmulya menurut penguasaan modal fisik tahun 2017

\begin{tabular}{llrr}
\hline \multirow{3}{*}{ Dusun } & \multirow{2}{*}{$\begin{array}{l}\text { Penguasaan } \\
\end{array}$} & Modal Fisik & \multicolumn{2}{c}{$\begin{array}{c}\text { Perubahan } \\
\text { (Setelah-sebelum) }\end{array}$} \\
\cline { 3 - 4 } & & Jumlah & $\%$ \\
\hline \multirow{3}{*}{ Dusun } & Rendah & -22 & $-73,3$ \\
Simargalih & Sedang & 14 & 46,7 \\
& Tinggi & 8 & 26,7 \\
\cline { 2 - 4 } & Total & 0 & 0,0 \\
\hline \multirow{4}{*}{ Dusun Griya } & Rendah & -23 & $-76,7$ \\
Indah & Sedang & -3 & $-10,0$ \\
& Tinggi & 26 & 86,7 \\
\cline { 2 - 4 } & Total & 0 & 0,0 \\
\hline
\end{tabular}

\section{Penguasaan Modal Finansial}

Jumlah tabungan yang diukur dalam penelitian berdasarkan rata-rata uang yang ditabung oleh responden, baik pada diri sendiri, perbankan atau orang lain. Hasil dari jumlah tabungan ini kemudian di kategorikan pada kelas rendah, sedang dan tinggi. Hasil ini kemudian juga dilihat perubahannya pada saat sebelum hingga setelah adanya industri.

Pada kelompok responden Dusun Simargalih, adanya peningkatan pada modal finansial diakui responden karena mulai hadirnya saluran atau tempat untuk menabung di tempat responden, seperti bank dan sekolah. Responden yang mulai menabung di bank karena ada anggota rumah tangganya yang bekerja di perusahaan yang gajinya menggunakan sistem transfer antarbank, meskipun tetap ada responden yang 
membuka tabungan di bank sebagai tempat menyimpan uang ketika ada keuntungan besar dari usahanya. Sementara itu, pada responden Dusun Griya Indah meningkatnya penguasaan modal finansial lebih disebabkan oleh mayoritas responden yang saat ini mulai bekerja dan memiliki usaha setelah adanya industri. Sebelum adanya industri, responden umumnya adalah pelajar dan belum memiliki pendapatn untuk digunakan dan ditabung.

Tabel 4 Perubahan jumlah dan persentase responden Desa Parungmulya menurut penguasaan modal finansial tahun 2017

\begin{tabular}{llrr}
\hline \multirow{2}{*}{ Dusun } & Penguasaan & \multicolumn{2}{c}{ Perubahan } \\
& Modal & (Setelah-sebelum) \\
\cline { 2 - 4 } & Finansial & Jumlah & $\%$ \\
\hline \multirow{3}{*}{ Dusun } & Rendah & -10 & $-33,3$ \\
Simargalih & Sedang & 10 & 33,3 \\
& Tinggi & 0 & 0,0 \\
\cline { 2 - 4 } & Total & 0 & 0,0 \\
\hline \multirow{2}{*}{ Dusun } & Rendah & -22 & $-73,3$ \\
Griya & Sedang & 21 & 70,0 \\
Indah & Tinggi & 1 & 3,3 \\
\cline { 2 - 4 } & Total & 0 & 0,0 \\
\hline
\end{tabular}

\section{Penguasaan Modal Sosial}

Pada pengukuran modal sosial kali ini, aspek yang dinilai mengenai jaringan yang dimiliki rumah tangga, frekuensi memanfaatkan jaringan dan kepercayaan rumah tangga pada jaringan yang dimiliki. Frekuensi dalam memanfaatkan jaringan ini dapat dilihat pula melalui kekuatan jaringan yang dimiliki oleh rumah tangga.

Berdasarkan Tabel 5, terlihat bahwa pada kelompok responden di Dusun Simargalih cenderung tidak mengalami perubahan berarti pada penguasaan modal sosial setelah hadirnya industri. Sedangkan pada kelompok responden di Dusun Griya Indah, perubahan justru terlihat meningkat pada kategori sedang sebesar 20,0 persen dan pada kategori rendah menurun sebesar 20,0 persen. Pada kategori tinggi, kelompok responden di Dusun Griya Indah tidak terjadi perubahan. Meski begitu, pada kelompok responden di Dusun Simargalih sebaran responden banyak dominan terdapat pada kategori sedang sebesar 70,0 persen. Modal sosial yang dimiliki oleh responden menentukan skala usaha yang dijalankan oleh masing-masing responden. Responden yang memiliki jaringan lebih luas, terutama memiliki jaringan ke orangorang di perusahaan, relatif memiliki usaha yang semain baik. Menurut Amalia (2016), tingkat kepercayaan dan kekuatan jaringan yang terhubung di dalamnya akan mempermudah seseorang mengakses suatu hal, yang dalam hal ini adalah perihal nafkah.

Tabel 5 Perubahan jumlah dan persentase rumah tangga di Desa Parungmulya menurut penguasaan modal sosial tahun 2017

\begin{tabular}{llrr}
\hline \multirow{2}{*}{ Dusun } & $\begin{array}{l}\text { Penguasaan } \\
\end{array}$ & Modal & \multicolumn{2}{c}{$\begin{array}{c}\text { Perubahan (Setelah- } \\
\text { sebelum) }\end{array}$} \\
\cline { 2 - 4 } & Sosial & 0 & 0,0 \\
\hline \multirow{3}{*}{ Dusun } & Rendah & -1 & $-3,3$ \\
Simargalih & Sedang & 1 & 3,3 \\
\cline { 2 - 4 } & Tinggi & 0 & 0,0 \\
\cline { 2 - 4 } Dusun Griya & Total & -6 & $-20,0$ \\
Indah & Rendah & 6 & 20,0 \\
& Sedang & 0 & 0,0 \\
\cline { 2 - 4 } & Tinggi & 0 & 0,0 \\
\hline
\end{tabular}

\section{Hubungan Kesempatan Usaha dengan Penguasaan Modal Nafkah}

\section{Dusun Simargalih}

Pada kelompok responden Dusun Simargalih, hubungan kesempatan usaha dengan penguasaan modal alam yaitu jumlah responden yang mengalami peningkatan pada kesempatan usaha terlihat lebih tinggi jumlahnya jika dibandingkan dengan responden yang tidak mengalami perubahan pada kesempatan usaha. Hampir seluruh responden setelah adanya industrialisasi ini mengalami peningkatan pada kesempatan usaha. Pada kesempatan usaha yang meningkat, hasil dominan justru ditunjukkan pada kelompok responden yang mengalami penurunan 
penguasaan modal alam yaitu sebesar 70,4 persen. Sementara responden yang mengalami peningkatan kesempatan usaha yang dibarengi dengan peningkatan penguasaan modal alam sebesar 25,9 persen. Respoden yang mengalami peningkatan kesempatan usaha yang dibarengi dengan penurunan penguasaan modal alam terlihat dari jenis mata pencaharian yang saat ini dilakukan oleh responden tidak lagi memiliki ketergantungan yang tinggi pada sumber daya alam, berbeda dengan sebelum adanya industri. Saat lanskap wilayah di desa berubah, sumber daya alam yang terkonversi diantisipasi rumah tangga melalui perubahan mata pencaharian yang di antaranya membuka usaha-usaha baru.

Pada hubungannya dengan penguasaan modal manusia, responden yang mengalami peningkatan kesempatan usaha lebih banyak dibarengi dengan peningkatan pada penguasaan modal manusia yaitu sebanyak 22 responden atau 81,5 persen. Setelah hadirnya industri, keahlian utama masyarakat yaitu bertani tidak dapat lagi diterapkan sehingga mereka memaksa diri mereka untuk mengembangakan keterampilan lain demi kelanjutan hidup. Ada pula responden yang mengalami peningkatan kesempatan usaha namun tidak dibarengi dengan perubahan pada penguasaan modal manusia. Responden ini merupakan responden yang umumnya sudah berusia lanjut dan kurang mampu memanfaatkan berbagai kesempatan dari hadirnya industri.

Pada kasus penguasaan modal fisik, sebanyak 96,3 persen responden mengalami peningkatan setelah hadirnya industri, sedangkan 3,7 persen lainnya tetap. Kelompok responden yang berhasil dalam usaha yang dijalankan memang banyak menginvestasikan penghasilan dalam bentuk barang, seperti televisi, motor, kulkas dan bangunan khusus untuk usaha. Sebelum adanya industri mereka tidak memiliki banyak perlengkapan rumah tangga, tetapi saat ini alat-alat seperti televisi, handphone dan kulkas merupakan barang yang sudah menjadi kebutuhan wajib bagi rumah tangga.
Pada penguasaan modal finansial didominasi oleh kesempatan usaha yang meningkat. Pada kelompok responden yang mengalami peningkatan pada kesempatan usaha ini, sebanyak 51,9 responden dibarengi dengan penguasaan modal finansial yang meningkat dan sebanyak 37,0 responden dibarengi dengan penguasaan modal finansial yang tetap. Meningkatnya penguasaan modal finansial disebabkan oleh meningkatnya kemampuan responden untuk menabung setelah adanya industri. Hal ini terjadi karena pendapatan yang diterima responden meningkat karena usaha yang dijalankan dan bertambahnya jumlah usaha yang dijalankan oleh responden. Sementara itu sebanyak 37,0 persen responden yang mengalami peningkatan pada kesempatan usaha namun tidak mengalami perubahan pada penguasaan modal finansial disebabkan oleh responden yang sudah melakukan kebiasaan menabung walau sebelum adanya industri atau saat ini memang tidak gemar menabung.

Pada penguasaan modal social, hasil dominan ditunjukkan pada responden yang mengalami peningkatan kesempatan usaha dibarengi dengan penguasaan modal sosial yang tetap sebesar 44,4 persen. Hasil ini tidak jauh berbeda dengan responden yang mengalami peningkatan penguasaan modal sosial. Faktor utama peningkatan penguasaan modal sosial menurut responden adalah berkat usaha yang dijalankan. Melalui usaha, semakin banyak jaringan yang bisa diajak bekerja sama sehingga berhasil meningkatkan penghasilan dan meningkatkan skala usaha. Selain terdapat responden yang mengalami peningkatan pada penguasaan modal sosial, ada pula responden yang mengalami penurunan pada penguasaan modal sosial yaitu sebesar 18,5 persen. Salah seorang responden mengatakan meski saat ini Ia memiliki usaha yang terbilang ramai karena adanya kawasan perusahaan, Ia merasa kedekatannya dengan warga jauh menurun dibanding sebelum adanya perusahaan. Adapun pengujian statistic hubungan-hubungan di atas melalui uji korelasi rank-spearman disajikan dalam Tabel 6. 
Tabel 6 Hasil Uji Korelasi Kesempatan Usaha dengan Modal Nafkah Responden Dusun Simargalih, 2017

\begin{tabular}{clcc}
\hline $\begin{array}{c}\text { Dampak } \\
\text { Industri }\end{array}$ & Modal Nafkah & $\begin{array}{c}\text { Koefisien } \\
\text { Korelasi }\end{array}$ & $\begin{array}{c}\text { Nilai } \\
\text { Signifikansi }\end{array}$ \\
\hline & Modal Alam & $-0,227$ & 0,228 \\
& Modal Manusia & $0,535^{*}$ & 0,002 \\
$\begin{array}{c}\text { Kesempatan } \\
\text { Usaha }\end{array}$ & Modal Fisik & $0,505^{*}$ & 0,004 \\
& Modal Finansial & 0,062 & 0,743 \\
& Modal Sosial & 0,418 & 0,022 \\
\hline
\end{tabular}

\section{Dusun Griya Indah}

Pada responden di Dusun Griya Indah yang mengalami peningkatan kesempatan usaha justru lebih banyak tidak dibarengi dengan perubahan pada penguasaan modal alam. Jumlah ini paling tinggi jika dibandingkan dengan responden yang mengalami penurunan atau peningkatan penguasaan modal alam. Kondisi Dusun Griya Indah merupakan perumahan dan dihuni oleh masyarakat yang memiliki ekonomi rata-rata relatif lebih tinggi jika dibandingkan dengan masyarakat yang tinggal di Dusun Simargalih. Selain itu, masyarakat di Dusun Griya Indah juga hampir seluruhnya pendatang dan bekerja sebagai buruh atau karyawan di perusahaan. Faktor sebagai pendatang ini merupakan faktor terbesar sehingga mayoritas responden tidak mengalami perubahan dalam penguasaan modal alam.

Pada hubungan kesempatan usaha dengan modal manusia, mayoritas reponden setelah hadirnya industri mengalami peningkatan pada kesempatan usaha dan dibarengi dengan peningkatan pada penguasaan modal manusia yaitu sebanyak 18 responden atau sebesar 66,7 persen. Jika mayoritas responden di Dusun Simargalih awalnya hanya memiliki kemampuan bertani, responden di Dusun Griya Indah justru awalnya tidak memiliki keahlian tertentu yang dapat digunakan untuk usaha. Kelompok responden ini sebelum adanya industri umumnya masih berstatus sebagai pelajar. Setelah adanya industri, mereka pindah ke Desa Parungmulya untuk bekerja di perusahaan-perusahaan yang ada di desa ini. Setelah memiliki pekerjaan sebagai karyawan, responden membuka usaha sebagai sumber pendapatan sampingan mereka. Dari usaha ini, ada responden yang belajar dengan orang lain untuk mengembangkan usahanya, ada pula yang merekrut orang lain untuk menjalankan usaha miliknya.

Pada hubungan kesempatan usaha dengan penguasaan modal fisik, responden Dusun Griya Indah memiliki kesamaan denga responden di Dusun Simargalih yaitu mengalami peningkatan modal fisik setelah hadirnya industry sebesar 96,3 persen. Akan tetapi, terdapat perbedaan pada modal fisik bagi mresponden di Dusun Griya Indah. Umumnya, masyarakat di Dusun Griya Indah memiliki modal fisik atau perlengkapan rumah tangga yang lebih lengkap. Hal ini bisa dilihat dari banyaknya responden yang memiliki $\mathrm{AC}$, mesin cuci dan mobil. Meski demikian, modal fisik yang dimiliki oleh responden ini tidak seluruhnya berasal dari pendapatan atas usaha yang dijalankan, beberapa juga berasal dari gaji bekerja sebagai karyawan di perusahaan.

Kelompok responden Dusun Griya Indah hasil menunjukkan hasil dominan pada responden yang mengalami peningkatan kesempatan usaha yang dibarengi dengan peningkatan pengusaan modal finansial sebesar 73,3 persen atau sebanyak 19 responden. Berdasarkan hasil wawancara yang dilakukan dengan responden, rata-rata responden di Dusun Griya Indah lebih rutin dalam menabung jika dibandingkan dengan kelompok responden di Dusun Griya Indah. Hal ini menunjukkan bahwa penguasaan modal finansial di kelompok responden Dusun Griya Indah terlihat lebih baik.

Sementara pada kelompok responden di Dusun Griya Indah, sebanyak 63,0 persen responden mengaku mengalami peningkatan penguasaan modal sosial. Sisanya atau sebesar 33,3 persen tidak mengalami perubahan pada penguasaan modal sosial. Sama seperti pada kelompok responden sebelumnya, responden yang mengalami peningkatan kesempatan usaha dan peningkatan modal sosial disebabkan jaringan 
yang mereka miliki lebih banyak dari hadirnya berbagai pekerja di perusahaan. Bahkan bagi kelompok responden yang mayoritas bekerja sebagai karyawan di perusahaan memiliki akses modal sosial yang lebih besar karena memiliki hubungan yang lebih kuat dengan para petinggi perusahaan. Sementara itu bagi responden yang mengalami peningkatan kesempatan usaha namun tidak mengalami perubahan pada penguasaan modal sosial disebabkan tidak terjadi perubahan signifikan saat mereka belum terkena dampak industri setelah mereka mengalami dampak industri.

Tabel 7 Hasil Uji Korelasi Kesempatan Usaha dengan Modal Nafkah Responden Dusun Griya Indah, 2017

\begin{tabular}{llcc}
\hline $\begin{array}{c}\text { Dampak } \\
\text { Industri }\end{array}$ & Modal Nafkah & $\begin{array}{c}\text { Koefisien } \\
\text { Korelasi }\end{array}$ & $\begin{array}{c}\text { Nilai } \\
\text { Signifikansi }\end{array}$ \\
& Modal Alam & $-0,057$ & 0,765 \\
& Modal Manusia & $0,559^{*}$ & 0,001 \\
Kesempatan & Modal Fisik & $0,674^{*}$ & 0,000 \\
Usaha & Modal Finansial & $-0,082$ & 0,668 \\
& Modal Sosial & 0,286 & 0,126 \\
\hline
\end{tabular}

\section{Hubungan Jual-beli Lahan dengan Penguasaan Modal Nafkah}

\section{Dusun Simargalih}

Pada hubungan jual-beli lahan dengan penguasaan modal alam, terdapat persentase yang sama yaitu 50,0 persen mengalami peningkatan jual-beli lahan dan 50,0 persen tidak mengalami perubahan pada jual-beli lahan. Responden yang mengalami peningkatan jual-beli lahan merupakan warga asli desa yang sebelum hadirnya industri memiliki lahan pertanian yang luas dan harus mereka jual demi kepentingan pembangunan kawasan industri di wilayahnya. Dari 50,0 persen responden yang mengalami peningkatan jual-beli lahan, sebanyak 80,0 diantaranya dibarengi dengan penurunan penguasaan modal alam dan 20,0 persen sisanya mengalami peningkatan penguasaan modal alam. Sementara itu pada responden yang tidak mengalami perubahan pada jual-beli lahan, sebanyak 60,0 persen mengalami penurunan penguasaan modal alam, 26,7 persen mengalami peningkatan penguasaan modal alam, dan sisanya sebanyak 13,3 persen tidak mengalami perubahan pada penguasaan modal alam. Hal ini disebabkan oleh profesi awal responden yaitu petani berlahan yang kemudian menjual lahan pertanian mereka sehingga sumber daya alam yang dapat mereka akses menjadi berkurang.

Pada hubungannya dengan penguasaan modal manusia, jumlah responden tertinggi yaitu responden yang mengalami peningkatan jual-beli lahan dan dibarengi dengan peningkatan penguasaan modal manusia sebesar 86,7 persen. Sementara itu responden yang tidak mengalami perubahan pada aktivitas jual-beli lahan namun mengalami peningkatan penguasaan modal manusia mencapai 73,3 persen. Responden yang mengalami peningkatan jual-beli lahan umumnya menggunakan hasil tersebut untuk membuka usaha non-pertanian dan memaksa mereka mengembangkan dan menambah keterampilan mereka melalui usaha yang dijalankan.

Sementara itu, responden yang mengalami peningkatan jual-beli lahan yang dibarengi dengan penguasaan modal fisik cukup besar yaitu 100,0 persen. Adanya responden yang mengalami peningkatan baik pada aktivitas jual-beli lahan dan penguasaan modal fisik karena responden yang telah menjual lahan pada saat pendirian kawasan industri dialihkan uang ke dalam bentuk investasi barang seperti motor atau membangun toko atau kontrakan. Sementara responden yang tidak mengalami perubahan dalam hal aktivitas jual-beli lahan namun mengalami peningkatan pada penguasaan modal fisik disebabkan kepemilikan perlengkapan yang dimiliki saat ini merupakan hal yang standar dimiliki oleh masyarakat.

Pada hubungan antara jual-beli lahan dengan modal finansial, jual-beli lahan yang mengalami peningkatan, hasil tertinggi ada pada responden yang dibarengi dengan penguasaan modal finansial yang tetap sebesar 46,7 persen dan yang dibarengi dengan pengusaan modal finansial meningkat sebesar 40,0 responden. Responden 
yang mengalami peningkatan jual-beli lahan dan peningkatan penguasaan modal finansial karena dari hasil jual-lahan ini sebagian ditabung atau membuat usaha. Usaha yang dimiliki sampai saat ini berhasil meningkatkan kemampuan rumah tangga untuk menabung.

Kelompok responden Dusun Simargalih paling banyak mengalami jual-beli lahan yang tetap dan dibarengi dengan penguasaan modal sosial yang juga tetap yaitu sebanyak delapan responden atau sebesar 53,3 persen. Tidak adanya perubahan karena saat proses pembebasan lahan, responden tidak terlibat langsung dengan para stakeholder, seperti petinggi perusahaan sehingga tidak ada jaringan yang meningkat yang dirasakan oleh responden. Dari hasil ini dapat dilihat bahwa aktivitas jual-beli lahan tidak terlalu mempengaruhi penguasaan modal sosial responden.

Tabel 8 Hasil Uji Korelasi Jual-beli Lahan dengan Modal Nafkah Responden Dusun Simargalih, 2017

\begin{tabular}{llcc}
\hline $\begin{array}{c}\text { Dampak } \\
\text { Industri }\end{array}$ & Modal Nafkah & $\begin{array}{c}\text { Koefisien } \\
\text { Korelasi }\end{array}$ & $\begin{array}{c}\text { Nilai } \\
\text { Signifikansi }\end{array}$ \\
\hline & Modal Alam & $-0,271$ & 0,184 \\
Jual-beli & Modal Manusia & 0,424 & 0,020 \\
Lahan & Modal Fisik & 0,405 & 0,026 \\
& Modal Finansial & $-0,027$ & 0,887 \\
& Modal Sosial & 0,309 & 0,097 \\
\hline
\end{tabular}

\section{Dusun Griya Indah}

Pada hubungan antara jual-beli lahan dengan modal alam lebih didominasi hasil yang tidak mengalami perubahan setelah dan sebelum adanya industri. Pada jual-beli lahan, sebanyak 63,1 persen responden tidak mengalami perubahan aktivitas jual-beli lahan dan tidak mengalami perubahan pada penguasaan modal alam. Responden yang tidak mengalami perubahan baik pada aktivitas jual-beli lahan maupun penguasaan modal alam disebabkan keadaan responden yang merupakan para migran sehingga tidak menemukan jual lahan di seperti kasus responden di Dusun Simargalih.
Hubungan antara jual-beli lahan dengan modal manusia, jumlah responden yang mengalami perubahan meningkat merupakan kelompok dengan jumlah yang tertinggi yaitu 66,7 persen sedangkan kelompok yang tidak mengalami perubahan yaitu 33,3 persen. Responden yang mengalami peningkatan penguasaan modal manusia dan dibarengi dengan peningkatan penguasaan jual-beli lahan yaitu 81,8 persen, sedangkan sebanyak 57,9 persen responden tidak mengalami perubahan jual-beli lahan namun mengalami peningkatan penguasaan modal manusia. Kelompok responden di Dusun Griya Indah yang mayoritasnya merupakan pendatang sehingga tidak mengalami perubahan dalam aktivitas jual-beli lahan, tetapi mereka tetap dapat meningkatkan modal manusia baik dalam menambah keahlian, mempekerjakan orang lain hingga meningkatkan pendidikan responden secara formal.

Hubungan antara aktivitas jual-beli lahan dengan penguasaan modal fisik didominasi oleh aktivitas jual-beli lahan yang tetap dan dibarengi dengan peningkatan penguasaan modal fisik. Seperti yang telah dibahas pada sub-bab sebelumnya bahwa sebagian besar responden di Dusun Griya Indah merupakan pendatang sehingga lebih banyak responden yang tidak mengalami jual lahan saat berdirinya kawasan industri. Akan tetapi, pada kelompok responden di Dusun Griya Indah terdapat peningkatan aktivitas jual-beli lahan yang juga dibarengi dengan peningkatan penguasaan modal fisik yaitu sebesar 90,9 persen. Adanya peningkatan aktivitas jual-beli lahan pada responden ini disebabkan oleh beli lahan yang dilakukan responden sebagai investasi untuk usaha maupun investasi tanah untuk masa mendatang.

Responden yang tidak mengalami perubahan jual-beli lahan namun mengalami peningkatan modal finansial merupakan hasil tertinggi yaitu 63,2 persen. Jenis usaha pada kelompok ini umumnya tidak diawali dengan membeli lahan seperti usaha catering dan warung yang digabungkan dengan bangunan rumah. Peningkatan modal finansial didapatkan dari hasil usaha tersebut yang mereka tabung di bank karena usaha yang dilakukan merupakan usaha 
sampingan sehingga jarang digunakan untuk membeli kebutuhan sehari-hari.

Hasil tertinggi pada penguasaan modal sosial terdapat pada kelompok responden yang mengalami peningkatan. Sementara itu hasil pada tabulasi silang paling tinggi ditunjukkan pada responden yang tidak mengalami perubahan pada jual-beli lahan namun mengalami peningkatan pada penguasaan modal sosial yaitu sebanyak 73,7 persen atau 14 responden. Responden yang mengalami peningkatan penguasaan modal sosial dari kebanyakan responden disebabkan oleh jaringan responden yang semakin luas dengan mendapat akses ke petinggi di perusahaan dan perbankan. Jaringan yang semakin luas ini tidak didapatkan responden dari hasil jual-beli lahan. Sementara itu responden yang mengalami peningkatan jualbeli lahan yang dibarengi dengan peningkatan penguasaan modal sosial disebabkan ada pula relasi atau jaringan yang didapat responden dari hasil membeli lahan di daerah tempat tinggalnya.

Tabel 9 Hasil Uji Korelasi Jual-beli Lahan dengan Modal Nafkah Responden Dusun Griya Indah, 2017

\begin{tabular}{llcc}
\hline $\begin{array}{c}\text { Dampak } \\
\text { Industri }\end{array}$ & Modal Nafkah & $\begin{array}{c}\text { Koefisien } \\
\text { Korelasi }\end{array}$ & $\begin{array}{c}\text { Nilai } \\
\text { Signifikansi }\end{array}$ \\
\hline & Modal Alam & 0,030 & 0,874 \\
Jual-beli & Modal Manusia & 0,112 & 0,554 \\
Lahan & Modal Fisik & 0,059 & 0,757 \\
& Modal Finansial & 0,346 & 0,061 \\
& Modal Sosial & 0,193 & 0,307 \\
\hline
\end{tabular}

\section{SIMPULAN DAN SARAN}

\section{Simpulan}

Kesimpulan dari penelitian ini, yaitu:

1. Dampak industrialisasi yang terjadi di Dusun Simargalih dan Dusun Griya Indah dilihat dari kesempatan usaha mengalami peningkatan jika dibandingkan keadaan sebelum responden merasakan hadirnya industrialisasi. Sementara itu dalam hal jual-beli lahan, hasil yang lebih tinggi ditunjukan pada kelompok responden di Dusun
Simargalih jika dibdandingkan hasil kelompok responden di Dusun Griya Indah.

2. Terjadi perubahan pada penguasaan kelima modal nafkah rumah tangga, baik itu pada rumah tangga di Dusun Simargalih maupun di Dusun Griya Indah.

3. Hasil uji korelasi menggunakan rank spearman antara dampak industrialisasi pedesaan dengan penguasaan modal nafkah rumah tangga menunjukan hasil yang variatif. Pada rumah tangga di Dusun Simargalih, kesempatan usaha memiliki hubungan pada penguasaan modal manusi, modal fisik dan sosial. Sementara jualbeli lahan memiliki hubungan pada penguasaan modal manusia dan modal fisik. Pada rumah tangga di Dusun Griya Indah, kesempatan usaha memiliki hubungan pada penguasaan modal fisik dan modal manusia, sedangkan jual-beli lahan tidak memiliki hubungan dengan kelima unsur modal nafkah.

\section{Saran}

1. Responden yang membuka usaha sebaiknya meningkatkan jejaring yang dimiliki untuk meningkatkan skala usaha atau meningkatkan pendapatan. Hal ini bisa dilakukan dengan membuat kelompok atau mebuka akses dengan perusahaan.

2. Perlu adanya penetapan lahan pertanian abadi di kawasan Desa Parungmulya ini, agar pengusaan modal alam bagi rumah tangga yang masih memanfaatkan sawah tidak semakin menurun.

3. Perlu adanya pertimbangan untuk menambahkan variabel migrasi masuk pada penelitian selanjutnya, sehingga hasil analisis antara dampak industrialisasi dengan nafkah menjadi lebih relevan.

\section{DAFTAR PUSTAKA}

Azzahra F. 2015. Pengaruh livelihood assets terhadap resiliensi nafkah rumah tangga petani pada saat banjir di Desa Sukabakti Kecamatan Tambelang Kabupaten Bekasi. [skripsi]. Institut Pertanian Bogor (ID): Departemen Sains Komunikasi dan Pengembangan Masyarakat.

BPS Kabupaten Karawang. 2013. Angka Sementara Hasil Sensus Pertanian tahun 2013. [internet]. Dapat diunduh pada: 
http://st2013.bps.go.id/st2013esya/booklet/st3 215.pdf. [diunduh 09 Maret 2017].

[BPS] Badan Pusat Statistik. 2015. Laju pertumbuhan produk domestik bruto atas dasar harga konstan 2000 menurut lapangan usaha , 200-2014. [internet]. Dapat diunduh pada: https://www.bps.go.id/linkTabelStatis/view/id/ 1202. [diunduh 05 Desember 2016].

[BPS] Badan Pusat Statistik. 2016. Penduduk 15 Tahun ke Atas yang Bekerja menurut Lapangan Pekerjaan Utama. Dapat diunduh pada: https://www.bps.go.id/linkTabelStatis/view/id/ 970. [diunduh 12 Februari 2017].

[BPS] Badan Pusat Statistik. 2016. Industri Besar dan Sedang: Konsep dan definisi. [internet]. Dapat diunduh pada: https://www.bps.go.id/Subjek/view/id/9\#subje kViewTab1|accordion-daftar-subjek1. diunduh 12 Februari 2017.

Baladina N, Anindita R, Putri R. 2012. Respon Petani Apel terhadap Industrialisasi Pertanian (kasus Desa Poncokusumo, Kecamatan Poncokusumo, Kabupaten Malang). J SEPA Vol. 8 No. 2. Februari: 51-182. Dapat diunduh pada: http://agribisnis.fp.uns.ac.id/wpcontent/uploads/2012/10/Jurnal-SEPA-92RESPON-PETANI-APEL-TERHADAPINDUSTRIALISASI-PERTANIAN.pdf. [diunduh 6 Desember 2016].

Chambers R, Conway GR. 1991. Sustainable rural livelihoods: practical concept for the 21st Century. Institute of Development Studies (UK). Dapat diunduh pada: http://www.ids.ac.uk/publication/sustainablerural-livelihoods-practical-concepts-for-the21st-century. [diunduh 12 Februari 2017].

Dharmawan AH. 2007. Sistem Penghidupan dan Nafkah Pedesaan: Pandangan Sosiologi Nafkah (Livelihood Sociology) Mazhab Barat dan Mazhab Bogor. Sodality: Jurnal Transdisiplin Sosiologi, Komunikasi dan Ekologi Manusia. Vol. 01 No. 02: Februari 2007.

Ellis F. 2000. Rural Livelihood Diversity in Developing Country. London (UK): Oxford University Press.

Gandi R. 2011. Pengaruh Industrialisasi Pedesaan terhadap Taraf Hidup Masyarakat Di RW 01 dan RW 09 Desa Benda, Kecamatan Cicurug,
Kabpaten Sukabumi, Provinsi Jawa Barat. [Skripsi]. Institut Pertanian Bogor (ID): Departemen Sains Komunikasi dan Pengembangan Masyarakat.

Kementerian Perindustrian. 2016. Kebijakan Industri Nasional tahun 2015-2019. Disampaikan pada rapat kerja Kementerian Perindustrian 16 Februari 2016. Dapat diunduh pada: http://www.kemenperin.go.id/download/11718 /Kebijakan-Industri-Nasional-Tahun-.[ Diakses pada 05 Desember 2016].

Mirajiani. 2003. Dampak industrialisasi dan perubahan sosial terhadap munculnya agresivitas masyarakat: Suatu analisis sosiologis (studi kasus Desa Guning Waja, Wilayah Industri Cilegon). Tesis. Institut Pertanian Bogor (ID): Program Studi Sosiologi Pedesaan.

Purwanto. 2003. Perubahan Pola Pencaharian Nafkah Masyarakat Petani di Sekitar Kawasan Industri (Kasus di Desa Ngoro, Kabupaten Mojokerto, Jawa Timur). [Tesis]. Sekolah Pasca Sarjana Institut Pertanian Bogor (ID): Program Studi Sosiologi Pedesaan. Dapat diunduh pada: http://repository.ipb.ac.id/handle/123456789/7 631. [diunduh pada 27 Desember 2016].

Singarimbun M. 2012. Metode Penelitian Survei. Jakarta: LP3ES.

Sulasmono BS. 1994. Respons masyarakat desa terhadap pembangunan industri besar kasus Desa Hardjosari, Kecamatan Bawen, Kabupaten Semarang, Jawa Tengah. Tesis. Institut Pertanian Bogor (ID): Program Pascasarjana Studi Pembangunan.

Sutrisna E. 2008. Dampak Industrialisasi terhadap Aspek Sosial Ekonomi Masyarakat. Jurnal Industri Perkotaan. Vol XII (Agustus 2008)/No. 22: 1743-1753. Dapat diunduh pada: ejournal.unri.ac.id/index.php/JIP/article/viewF ile/575/568. [diakses pada 20 November 2016].

Sztompka P. 1993. Sosiologi Perubahan Sosial. Jakarta (ID): Prenada.

White B. 1990. Agro-industri, Industrialisasi pedesaan dan Transformasi Pedesaan, dalam Sajogyo dan M Tambunan (ed), Industrialisasi Pedesaan. Jakarta (ID): PT Sekindo Eska Jaya. 